\title{
Diseases and disorders associated with different stages of crop development and factors that determine the incidence in Hass avocado crops
}

\author{
Joaquín Guillermo Ramírez-Gil ${ }^{1 *} \mathbb{D}$, Juan Gonzalo Morales-Osorio ${ }^{2}$
}

10.1590/0034-737X202168010009

\begin{abstract}
Hass avocado production systems in Colombia have increased to become the third largest area planted for fruit production. A number of factors that limit productivity such as diseases have become of high economic importance. The objectives of this study were to identify the causal agents associated with pathologies in Hass avocado crops in different stages of development and to determine main environmental factors associated with their incidence. This work was conducted over a period of eight years (2009-2016), during which plots and nurseries were monitored. Results showed that the most common disease of Hass avocado was avocado wilt complex (AWC) caused mainly by Phytophthora cinnamomi. In addition, it was found that pathogens such as Lasiodiplodia theobromae, Colletotrichum gloeosporioides sensu lato, and Phytophthora palmivora, can affect diverse tissues of avocado plants, appearing in different stages of crop development. Incidence of different pathologies in commercial plots were influenced by technological level, the sampling season (rainy and dry), and environmental and topographical variables such as precipitation, slope and elevation. This work presented a holistic approach for analysis of pathologies in Hass avocado crops, which were determined by the stage of crop development, environmental and topographic variability and the technological level of the productive system.
\end{abstract}

Keywords: environmental variables; Phytophthora cinnamomi; Lasiodiplodia theobromae.

\section{INTRODUCTION}

Avocado fruit production (Persea americana Mill) represents an important percentage of the agricultural sector in different countries, such as Mexico, Indonesia, the United States of America, Dominican Republic, Colombia, Chile, Peru, and others (FAO, 2020). Avocado diseases may cause reduction of yield, fruit quality and plant death limiting productivity by increasing costs; so they are a serious threat to crop sustainability (RamírezGil et al., 2017b).

The root rot (RR) caused by the oomycete Phytophthora cinnamomi Rands is considered the most important diseased in avocado (Zentmyer, 1980; RamírezGil et al., 2017b; Hardham \& Blackman, 2018). In addition, other microorganisms can be associated with RR, standing out: Verticillium sp., Armillaria mellea (Vahl) P. Kumm., Cylindrocladium sp., Rosellinia sp., Fusarium sp., Phymatotrichum omnivurum (Duggar) Hennebert., Cylindrocarpon sp., Pythium sp., Lasiodiplodia theobromae (Pat.) Griffon \& Maubl. (=Botryodiplodia theobromae), among others (Zentmyer, 1984; Vitale et al., 2012; Parkinson et al., 2017; Valencia et al., 2018; RamírezGil \& Morales-Osorio, 2019). On the other hand of abiotic origin, hypoxia-anoxia and root atrophy have been reported as disorders that induced RR (Stolzy et al., 1967; Sanclemente et al., 2014; Ramírez-Gil \& Morales-Osorio, 2019).

Under tropical condition, RR is re-named as avocado wilt complex (AWC), to describe a multi-complex diseases associated with different causal agents. AWC which can

\footnotetext{
Submitted on April 24th, 2020 and accepted on October 18th, 2020.

${ }^{1}$ Universidad Nacional de Colombia sede Bogotá, Facultad de Ciencias Agrarias, Departamento de Agronomía, Bogotá, Colombia. jgramireg@unal.edu.co,

${ }^{2}$ Universidad Nacional de Colombia sede Medellín, Facultad de Ciencias Agrarias, Departamento de Ciencias Agronómicas, Medellín, Colombia. jgmoraleso@unal.edu.co

"Corresponding author: jgramireg@unal.edu.co.
} 
be of biotic and abiotic origins, and can affect various tissues of avocado in all stage of productive system, causing similar aerial expressions, expressed as foliar yellowing, tissue flaccidity, growth retardation, excessive flowering and fructification in adult trees, defoliation, dieback, root rot and plant death (Ramírez-Gil, 2018; Ramírez-Gil \& Morales-Osorio, 2019).

AWC affects avocado roots mainly; however, other microorganisms have been reported affecting different tissues and organs of the avocado plant such as leaves, stems, flowers and fruits. Their relevance and economic importance depends on the plant variety, edaphoclimatic conditions of the orchard and agronomical management of the productive system. The most common pathogens are: Sphaceloma perseae Jenkins, Colletotrichum gloeosporioides (Penz.) Penz. \& Sacc. (teleomorph= Glomerella cingulata (Stoneman) Spauld. \& H. Schrenk), Pseudocercospora purpurea (Cooke) Deighton. (= Cercospora purpurea), Rhizopus stolonifer Ehrenb. (Fr) Vuill. Dothiorella sp., L. theobromae, among others (Zentmyer, 1984; Menge \& Ploetz, 2003; APS, 2017; Giblin et al., 2018; Ramírez-Gil \& Peterson, 2019).

Disease incidence, severity and mortality are usually evaluated during defined time periods, and in a particular stage of crop development (e. g., seedlings, vegetative growth, and productive stage). However, disease epidemics show very complex patterns of variation through time and space of multi-causal origin (Madden et $a l ., 2007)$. Despite of their importance, several aspects are ignored when monitoring, studying and managing most avocado diseases, such as the stage of crop development when each disease may be more aggressive and in consequence more limiting, the spatial and temporal variation that pathogen populations may exhibit, the technological level of each farm, edaphoclimatic and topographical conditions where the orchard is located and others.

The present work had two objectives; (i) to identify the causal agents associated with diseases of avocado cv. Hass plants in different tissues such as roots, stems, leaves, flowers and fruits in different stages of crop development (nursery, vegetative growth and fruit production); and (ii) to determine incidence of each pathology in crop fields and their relationship with the technological level of the farm, the sampling season, and environmental and topographical variables.

\section{MATERIALS AND METHODS}

\section{Localization and diagnosis of pathologies and disorders in Hass avocados}

Data for this study were obtained from nurseries and commercial plots of avocado cv. Hass through a period of eight years from 2009 to 2016, located in the Northern, Eastern and Southwestern regions of the department of Antioquia, Colombia (Figure 1). Avocado crops were monitored during all stages of development (Ramírez-Gil et al., 2017b). All stages were described in detail in Table 1. Monitored plots were located between 1800 and $2500 \mathrm{~m}$ of elevation, with annual average temperature between 14 and $20^{\circ} \mathrm{C}$, precipitation of 1800 $2600 \mathrm{~mm}$ and relative humidity of 75-95\%. All avocado trees sampled were of the Hass variety grafted in West Indian rootstock and at planting distances of $5 \times 6,5 \times$ $7,6 \times 6,6 \times 7$, and $6 \times 4 \mathrm{~m}$.

Each disease was diagnosed by a polyphasic approach, which included a suitable symptomatic description, isolation of microorganisms, pathogenicity test, morphological characterization and genetic identification (Ramírez-Gil \& Morales-Osorio, 2019). Abiotic factors were identified, measured and corroborated based on multi-step approach (Ramírez-Gil \& MoralesOsorio, 2019). This process was developed with each tissue sample associated with specific symptoms observed in plants under field and seedling in nurseries conditions.

\section{Determination of incidence and mortality of each disease and disorder in the different stages of development of Hass avocado crops}

Six Nurseries and 20 plots were monitored every two months for 8 years (2009-2016) (Figure 1). The number of plants to be sampled and measured were selected based on a simple random sampling, using the formula of maximum variance (Cochran, 1977). In each nursery or crop plot, polyphasic diagnosis of each diseased or disorder was performed based on methodology reported before without any further technical intervention.

Incidence and mortality of each positively diagnosed disease or disorder were determined using equations one and two. For the nursery stage (stage 1), seeds, roots, stems and leaves were evaluated. For plants in the field during the initial vegetative growth stage 2 (vegetative stages), roots, stems and leaves were analyzed. In stages 3 and 4, associated with the beginning and stabilization of fruit production, roots, stems, leaves, flowers and fruits, were tested (Table 1). For incidence and mortality of each disease and disorder, mean and standard deviation were determined.

Equation 1. $I=\frac{D P}{T P} * 100$, where: $\mathrm{I}=$ incidence in \%; DP: diseased plants; TP: total plants.

Equation 2. $M=\frac{D P}{T D P} * 100$ where, M: mortality in $\%$; DP: dead plants; TDP: total diseased plants 
Determination of disease incidence in Hass avocado plots and its relationship with the technological level and environmental variables

Sampling and collection of information were performed in 46 avocado production systems based on a proportional stratified sampling, according to number of plots planted in each region in Antioquia, Colombia (Figure 1). In each plot, the number of plants sampled was obtained by simple random sampling, using the formula of maximum variance (Cochran, 1977). Sampling was carried out for six time periods during the years 2011-2012, 2013-2014 and 20152016, one during the dry season (December-January) and the other one during the rainy season (April-May). In each period, roots, stems, leaves, flowers and fruits of

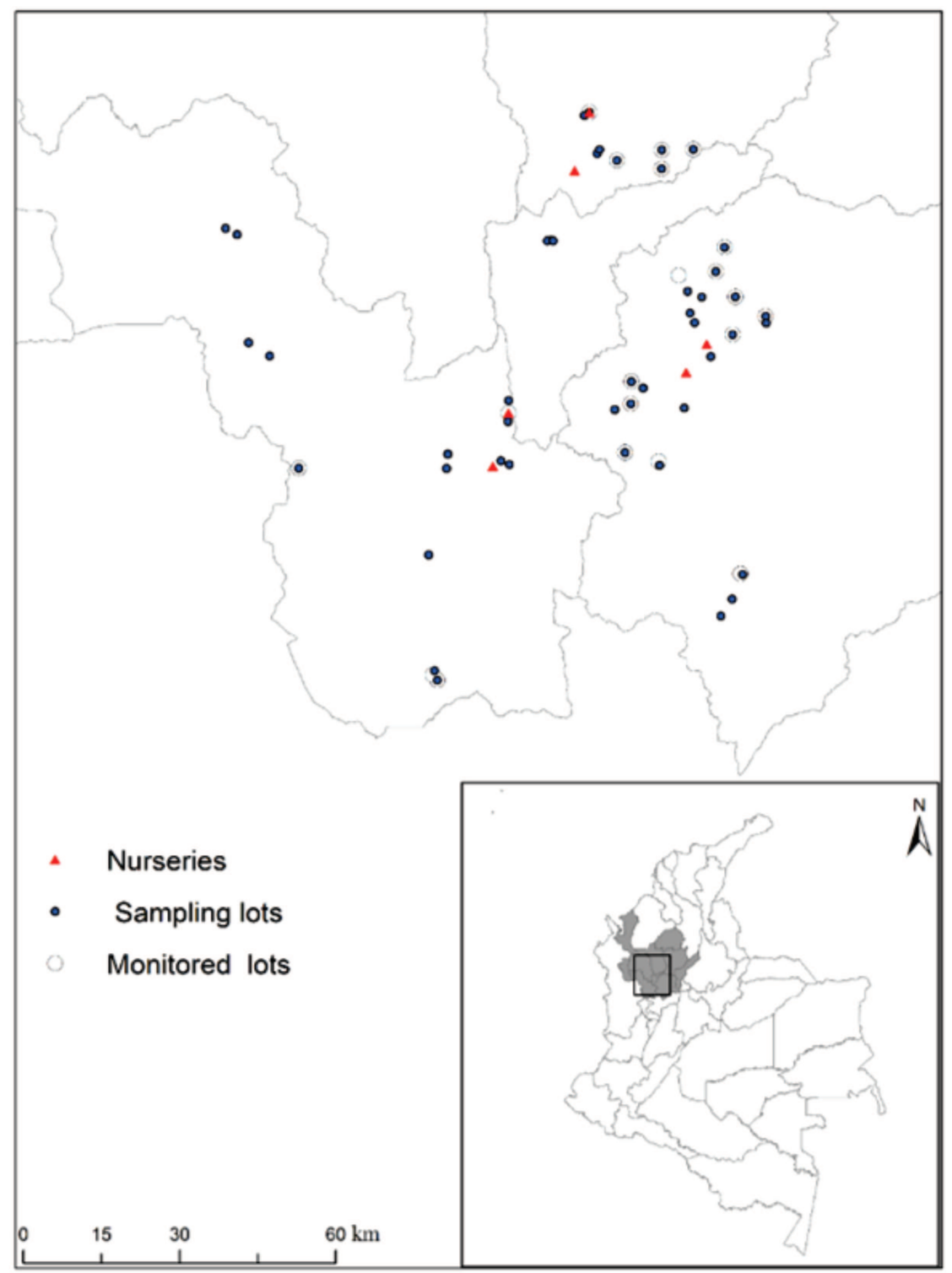

Figure 1: Localization of nurseries, monitored and sampling lots of Hass avocado.

Table 1: Stages of Hass avocado crop development for a seven years time period

\begin{tabular}{llll}
\hline $\begin{array}{l}\text { Crop } \\
\text { Stage }\end{array}$ & Name of crop stage & $\begin{array}{l}\text { Duration } \\
\text { (Months) }\end{array}$ & Features \\
\hline 1 & Nursery & $0-12$ & Germination, acclimatization, grafting and endurance \\
2 & Establishment into field conditions & $12.1-24$ & Seedling transfer into the field and initial development \\
3 & Production & $24.1-60$ & Start of production with sustained increase each year \\
$4^{\text {a }}$ & Production plateau & $>60.1$ & Production reaches the maximum \\
\hline
\end{tabular}

${ }^{a}$ In the present work this stage was evaluated for 24 months starting from the fifth to the seventh year of fruit production. 
each plant selected per plot were evaluated by the polyphasic approach previously described. Incidence was determined using the equation 1 described above.

The environmental variables included in the evaluation were temperature $\left({ }^{\circ} \mathrm{C}\right)$, precipitation $(\mathrm{mm})$ and relative humidity $(\%)$, obtained from weather stations (WatchDog serie $2000{ }^{\mathrm{TM}}$ ) located in some of the plots (two in the Southwestern, and three in the Eastern and Northern). Environmental data for the plots where no stations were available, were obtained by interpolation using data from the climatic network available at Ideam, Colombia (Institute of hydrology, meteorology and environmental studies), using the Higher Order Delaunay Triangulations (HODTs) (Gudmundsson et al., 2002), implemented in R (R Development Core Team, 2020). These variables were complemented with perimeter and topographic data obtained for each avocado plot using a GPS equipment (Trimble Serie GeoXT) adjusted under the projection system UTM WGS 84 Zone $18 \mathrm{~N}$. Elevation (E), slope in degrees (SD), slope in percentage (SP), Terrain Ruggedness Index (TRI) and Topographic Position Index (TPI), were obtained from a GMTED of digital elevation model (DEM), with spatial resolution of $230 \mathrm{~m}$ (https://topotools.cr.usgs.gov/GMTED_viewer/). These processes were performed using the ggplot, raster, and rgda packages available in $\mathrm{R}$ ( $\mathrm{R}$ Development Core Team, 2020).

To reduce dimensionality, further variable correlations among all environment and topographic variables, were applied. We eliminated variables that presented Pearson correlation coefficients $\geq 0.8$. Then, given the presence of extreme data and non-normal distribution, multiple correlation analysis using the Spearman correlation was performed between environmental variables, topographic variables and incidence of each disease and disorder. Analyzes were performed using R (R Development Core Team, 2020).

In addition, each plot was classified in a technological level (TL) as low, medium, and high (Ramírez-Gil et al., 2017b), and for each plot and level, the incidence of each disease and disorder were determined. The concept (TL) is associated with a series of agronomic and management practices made during all productive stages in avocado plots, which have been related through statistical and mathematical relationships with different levels of incidence, severity, mortality and productivity (RamírezGil et al., 2017b). Using the analysis of variance, the relationship between each technological level and incidence was determined. Since the number of plants and plots in each category was different, the test proposed by Dunnett, Tukey and Kramer was performed for multiple comparisons, using the algorithm available in the DTK package (Lau, 2013) implemented in $R$.

\section{RESULTS}

\section{Incidence and mortality caused by each causal agent during the different stages of development of Hass avocado crops}

For stage 1 (nursery) the most important pathology was AWC, which was associated to different causal agents both of biotic and abiotic origin that induced symptoms such as generalized wilt, stunted growth, foliar yellowing, root rot and damping off (Table 2). Phytophthora cinnamomi excelled all other causal agents causing AWC, showing an incidence of $12.2 \%$ and a mortality of $35.8 \%$. Root atrophy caused by a physical barrier in the plastic bag which halts plant growth and development, registered $4.6 \%$ of incidence and $3 \%$ of mortality (Figure $2 \mathrm{~A}$ ). Others causal agents associated with AWC were hypoxia-anoxia and the microorganisms Pythium sp. (Pythium sp., Pythium cucurbitacearum and Pythium vexans), Fusarium oxysporum sensu lato, Cylindrocarpon sp. (Cylindrocarpon destructans and Cylindrocarpon sp.), Phytophthora palmivora, Verticillium sp. (Verticillium albo-altrum and Verticillium dahliae), and Rosellinia sp., with incidences between 3.1 and $1 \%$. Many of diseases and disorder were asymptomatic (Figure $2 \mathrm{~A}$ ).

In addition to the root rot pathogens, Colletotrichum gloeosporioides sensu lato was found inducing seedling dieback and rot in the grafting zone between the bud and the scion with incidences of 1 and $4.3 \%$, respectively. Affecting the grafting zone also was found $L$. theobromae with $5.5 \%$ of incidence. Bud-scion incompatibility and canker in the base of the stem caused by Phytohpthora sp. (P. cinnamomi and P. palmivora), exhibited incidences of 3.2 and $1.8 \%$, respectively (Figure $2 \mathrm{C}$, Table 2 ). Foliage was found to be affected by P. palmivora with incidence of $3.5 \%$, causing leaf blight, followed by the algal leaf spot caused by $C$. virescens ( $2.5 \%$ of incidence) and the leaf spot caused by Pestalotia sp. (incidence of 2\%) (Figure $2 \mathrm{C}$ ). On the other hand Penicillium sp. was found associated to cotyledon rot with an incidence $<2 \%$ (Figure 2C).

Associated with AWC Fusarium oxysporum sensu lato caused the highest mortality with $60.3 \%$, determined as the number of dead plants over the total number of diseased plants in each evaluated development stage, followed by $P$. cinnamomi, Rosellinia sp. and Verticillium sp. (Verticillium albo-altrum and Verticillium dahliae) with 35.8, 28.3 and $25.4 \%$, respectively (Figures $2 \mathrm{~B}$ ). With respect to foliage diseases and disorders high mortality was recorded (> $51.3 \%$ ) when seedlings or seeds were infected by Colletotrichum gloeosporioides sensu lato and $L$. theobromae, meanwhile remaining causal agents caused less than $10 \%$ of the recorded mortality (Figure 2 D). 
During the second stage of crop development, corresponding to from plant transfer to the field to 24 months old, incidence of AWC induced by the different causal agents did not show significant variation when compared with the nursery stage (Figure $3 \mathrm{~A}$ ), exception made for hypoxia-anoxia, which exhibited a increase of $260 \%$. For this stage, incidence of pathologies in stem and foliage were similar to those identified in the nursery stage, with the exception of Phomopsis sp. spot (0.6\%), fumagina by Capnodium sp. $(0.5 \%)$ and the abiotic problems associated to herbicide toxicity (1\%) and hail damage (0.6\%) (Figure $3 \mathrm{~A})$. Mortality values were similar to those found during the nursery stage for $P$. cinnamomi, Fusarium oxysporum sensu lato, L. theobromae and Colletotrichum gloeosporioides sensu lato, but a significant increase in mortality caused by hypoxia-anoxia $(100 \%)$ and root atrophy (526\%) was observed in this stage (Figure $3 \mathrm{~B}$ ).
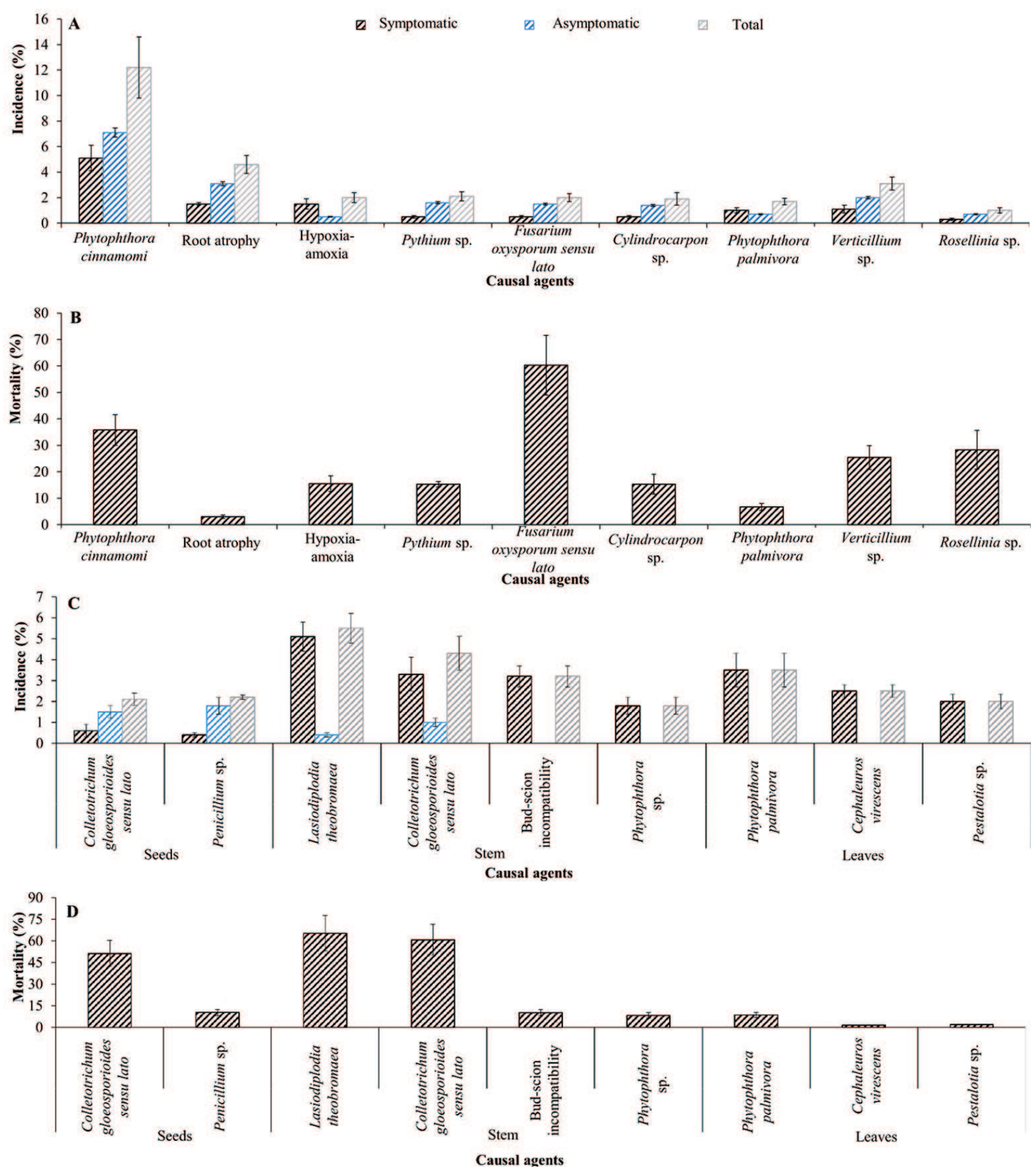

Figure 2: Incidence and mortality associated with different pathogens and disorders causing rot root (A and B), seeds, stems and leaves (C and D) in nurseries of Hass avocado. Error bars represent the confidence interval of the mean. 
Table 2: Etiology and symptoms of diseases and disorders identified in Hass avocado

\begin{tabular}{|c|c|c|c|c|}
\hline Type & Name of causal agents & Pathology or disorders & Affected tissueds & Symptoms \\
\hline Biotic & Phytophthora cinnamomi & Wilt complex & Roots and stems & Root rot, wilting, stem canker. \\
\hline Abiotic & Hypoxia-Anoxia & Wilt complex & Roots & Root rot and wilting \\
\hline Abiotic & Root atrophy & Wilt complex & Roots & Root atrophy and wilt complex \\
\hline Biotic & Verticillium $\mathrm{sp}^{1}$ & Wilt complex & Roots and stems & Root rot and hemilateral wilt \\
\hline Biotic & Lasodiplodia theobromae & Wilt complex, graft death, dieback, stem end rot & Stems and fruits & Wilting, graft death, dieback, and stem end rot \\
\hline Biotic & Phytophthora palmivora & Wilt complex and Seedling blight & Roots, stems and leaves & Root rot, stem canker and seedling blight \\
\hline Biotic & Fusarium oxysporum sensu lato & Damping off and wilt complex & Root and stem & Damping off and wilting \\
\hline Biotic & Rosellinia sp. & Wilt complex & Roots & Root rot and wilting \\
\hline Biotic & Cylindrocarpon $\mathrm{sp}^{2}$. & Wilt complex & Roots & Root rot and wilting \\
\hline Biotic & Pythium $\mathrm{sp}^{3}$. & Damping off and Wilt complex & Roots and stems & Damping off, root rot and wilting \\
\hline Biotic & Colletotrichum gloeosporioides sensu lato & Embryo, graft death, dieback and anthracnose & Seeds, stems and fruits & Embryo, graft death, dieback and antracnose \\
\hline Abiotic & Graft incompatibility & Graft incompatibility & Stems & Graft incompatibility \\
\hline Biotic & Ceplaleuros virescens & Algal spot & Leaves & Algal spot in leaves \\
\hline Biotic & Pestalotia sp. & Leaf spots and stem end rot & Leaves and fruits & Leaf spots and stem end rot \\
\hline Biotic & Capnodium sp. & Fumagina & Leaves and fruits & Dieback \\
\hline Biotic & Phomopsis sp. & Phomopsis spot & Leaves & Leaf spot \\
\hline Bitic & Pseudocercospora purpurea & Cercospora spot & Leaves and fruits & Spot in leaves and fruits \\
\hline Abiotic & Sunburn & Sunburn & Stem, leaf and fruit & Sunburn damage \\
\hline Abiotic & Hailstorm & Hailstorm damage & Leaf, stem and fruits & Damage in leaves, stems and fruits \\
\hline
\end{tabular}

Leaf, stem and fruits

Damage in leaves, stems and fruits 
During stages 3 and 4, characterized by rapid growth of trees and stabilization of fruit production, AWC incidence by Pythium sp. (Pythium sp., Pythium cucurbitacearum and Pythium vexans), Fusarium oxysporum sensu lato, and Cylindrocarpon sp., (Cylindrocarpon destructans and Cylindrocarpon sp.) significantly decreased; meanwhile remained within similar values for other causal agents, respect to other stages of crop development. Incidence of disease in the grafting region and dieback caused by $L$. theobromae and Colletotrichum gloeosporioides sensu lato, decreased $(\mathrm{P}<0.05)$; however, canker in the base of the stem by Phytophthora sp., (P. cinnamomi and P. palmivora) and bud-scion incompatibility, increased. Foliage diseases showed incidences lower to $3.5 \%$. In addition, the purple spot caused by $P$. purpurea with $1 \%$ of incidence was identified in the present work for the first time in this stage (Figures $4 \mathrm{~A}$ and $\mathrm{C}$ ).

During stages 3 and 4 of avocado crops, diseases in fruits began to be detected. In these stages the highest incidence was scored for sunburn fruit damage (2.5-4\%), followed by anthracnose by Colletotrichum gloeosporioides sensu lato (1-1.5\%), stalk rot by $L$. theobromae and Pestalotia sp. (0.5-1.5 and 0.06-1.2\%, respectively), herbicide damage (1\%) and fruit damage by hail (0.5-0.5\%) (Figure $4 \mathrm{~A}$ and C, Table 2).

Reduced mortality by $P$. cinnamomi was observed during stages 3 and 4 . For other causal agents of AWC and for pathogens causing diseases in stems and foliage, mortality values remained to similar levels as were recorded found in the previous stage (Figure $4 \mathrm{~B}$ and D).

\section{Relationship between disease incidence in cultivated plots with the technological level of the farm and environmental variables}

As expected, AWC caused by P. cinnamomi was the most relevant pathogen in the avocado plots evaluated. At intermediate level were found the disorders caused by hypoxia-anoxia and root atrophy and the fungal pathogen microorganism Verticilium sp. (Verticillium albo-altrum and Verticillium dahliae). The remaining microorganisms identified as associated to AWC showed incidence values below 4\% (Figure $5 \mathrm{~A}$ ). Diseases affecting stems, foliage and fruits were caused predominantly by Colletotrichum gloeosporioides sensu lato and L. theobromae, in addition to the alga $C$. virescens and to a lesser extent Capnodium sp. Other causal agents exhibited incidences lower than 2\% (Figure $5 \mathrm{~B}$ ).

In general, a significant $(\mathrm{P}<0.05)$ and inverse relationship was found between technological level and incidences of the causal agents associated with pathologies and abiotic disorders in avocado (e.g., the highest incidences were related to the lowest technological level used for farm management), with the exception of the damage caused by herbicide, sun light, hail and bud-scion incompatibility where no statistical ( $P$ $>0.05$ ) relationship was found with the technological level of each evaluated plot (Figure 5 A). Differences were more
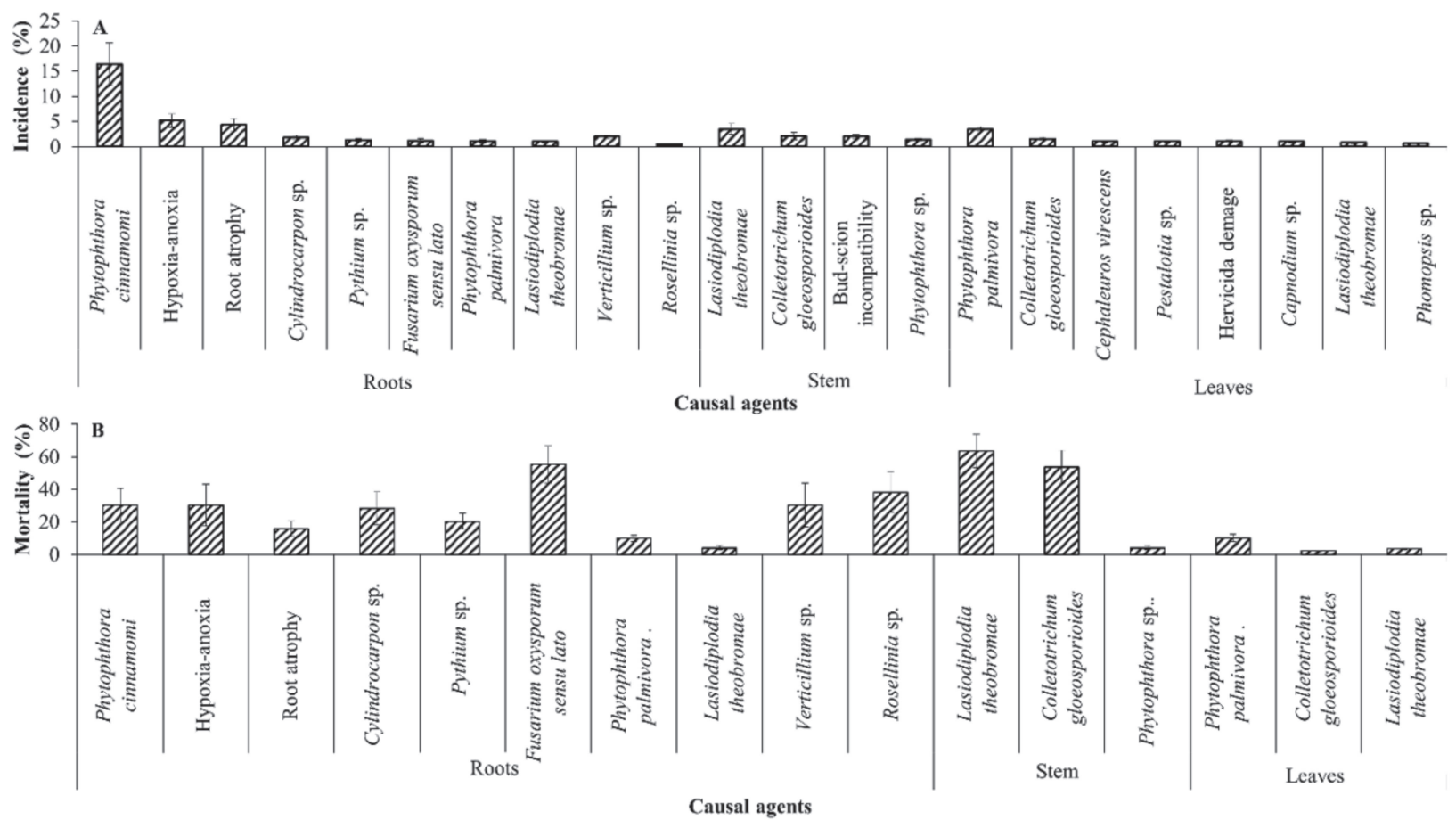

Figure 3: Disease incidence and mortality in transfer from nursery to the field conditions production of Hass avocado. Error bars represent the confidence interval of the mean. 
evident between the low and high technological level, with reduction in the incidence values for the high level when compared to the low level of $68.3,90.17,91.8,133$, $86.6,106.6,56,88,110$ and $42.8 \%$ for $P$. cinnamomi, hypoxiaanoxia, root atrophy, Cylindrocarpon sp. (Cylindrocarpon destructans and Cylindrocarpon sp.), Pythium sp. (Pythium sp., Pythium cucurbitacearum and Pythium vexans), Fusarium oxysporum sensu lato, $P$. palmivora, L. theobromae, Verticillium sp. (Verticillium albo-altrum and Verticillium dahliae) and Rosellinia sp., respectively (Figure $5 \mathrm{~A}$ ).

For foliage pathogens, the incidence of $L$. theobromae, Colletotrichum gloeosporioides sensu lato, P. palmivora,

Pestalotia sp., Capnodium sp., C. virescens, Phomopsis sp., and $P$. purpurea significantly $(\mathrm{P}<0.05)$ decreased 96 , $81,52,100,150,25,50$ and $100 \%$, respectively, in the high technological level when compared to the low technological level (Figure 5 B).
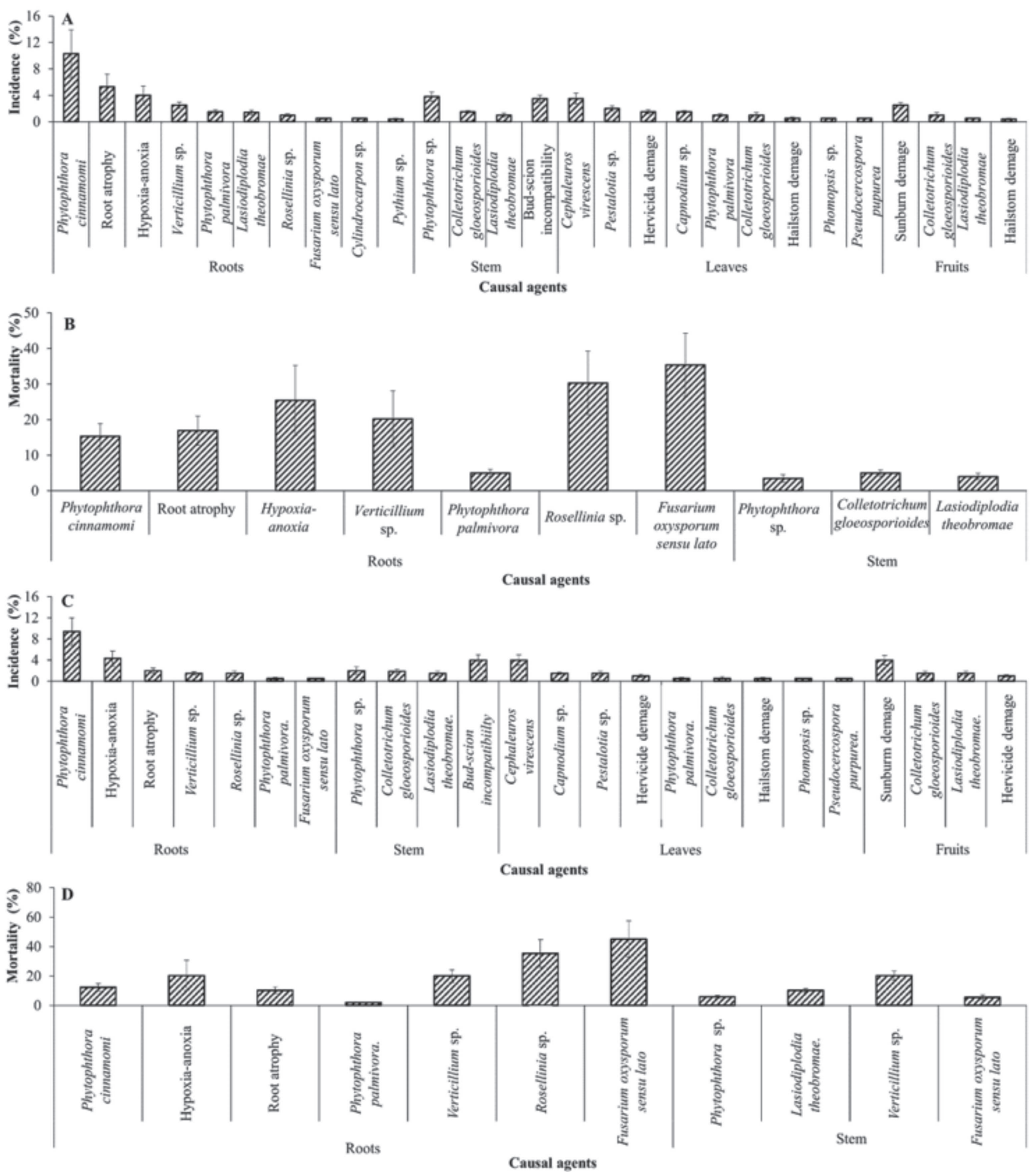

Figure 4: Incidence and mortality of causal agents of pathologies under production stages of Hass avocado. A and B: stage 3. C and D: stage 4. Error bars represent the confidence interval of the mean. 
A second factor affecting disease incidence was the season when sampling was performed, with the exception of damage caused by herbicide, sun light, hail and budscion incompatibility. During the dry season all diseases of biotic origin were significantly reduced between 15 $30 \%$, compared to values obtained during the rainy season $(\mathrm{P}<0.05)$. Remarkably but not surprising, the disorder caused by hypoxia-anoxia was reduced by $454 \%$ on average during the dry season (Figure $5 \mathrm{~A}$ ).

The third factor that influenced incidence values were the environmental and topographic variables. A significant and positive relationship was observed (Spearman correlation and $P$ value) between disease incidence by $P$. cinnamomi $(0.31 *)$, hypoxia-anoxia $(0.66 * * *), L$. theobromae $(0.32 *)$, Rosellinia sp. $(-0.38 *)$ and $C$. virescens $\left(0.34^{*}\right)$ with precipitation. Elevation was positively correlated with incidence of Capnodium sp. (0.36*), Colletotrichum gloeosporioides sensu lato (0.63**), Phomopsis sp. $\left(0.36^{*}\right)$ and negatively with $P$. purpurea $\left(-0.36^{*}\right)$, L. theobromae $\left(-0.71^{* * *}\right)$, P. palmivora $(-0.47 * *)$ and Rosellinia sp. $\left(-0.58^{*}\right)$. The slope of the crop plot showed a significant and negative relationship with $P$. cinnamomi (-0.40*) and hypoxia-anoxia (-0.56***) (Figure 6).

\section{DISCUSSION}

AWC, induced by several causal agents but from which stands out $P$. cinnamomi, was found to be the most limiting disease in all stages of crop development during the eight years of evaluation. This pathology has been widely recorded as the most important around the world (Zentmyer, 1980; Ramírez-Gil et al., 2017b; Hardham \& Blackman, 2018; Ramírez-Gil, 2018). In addition, other causal agents infecting roots exhibited severity and mortality values higher than those recorded for foliar diseases.

During the nursery stage and transfer of seedlings to the field conditions, Cylindrocarpon sp., Fusarium oxysporum sensu lato and Pythium sp., causing damping off and root rot, were more important, but their relevance decrease in the following stages (Vitale et al., 2012; Weiland et al., 2013; Ramírez-Gil \& Morales-Osorio, 2019). In contrast, L. theobromae, Verticillium sp., Phytophthora sp., Rosellinia sp., hypoxia-anoxia and root atrophy, affected more avocado trees during the field stages than in nursery.

Different factors affected disease appearance during the crop stages tested. Nursery sanitation is a key factor to consider, which includes disease-free seedlings, since infected plant material may transfer inoculum in an asymptomatic way to crop fields causing high incidence and mortality and disease dissemination (MacDonald et al., 1994; Bate et al., 2016). Change in climatic conditions such as high humidity may induce conditions of hypoxiaanoxia or favor P . cinnamomi development (Stolzy et al., 1967; Zentmyer, 1980; Kinal et al., 1993; Ramírez-Gil \& Morales-Osorio, 2019). Inoculum dynamics including

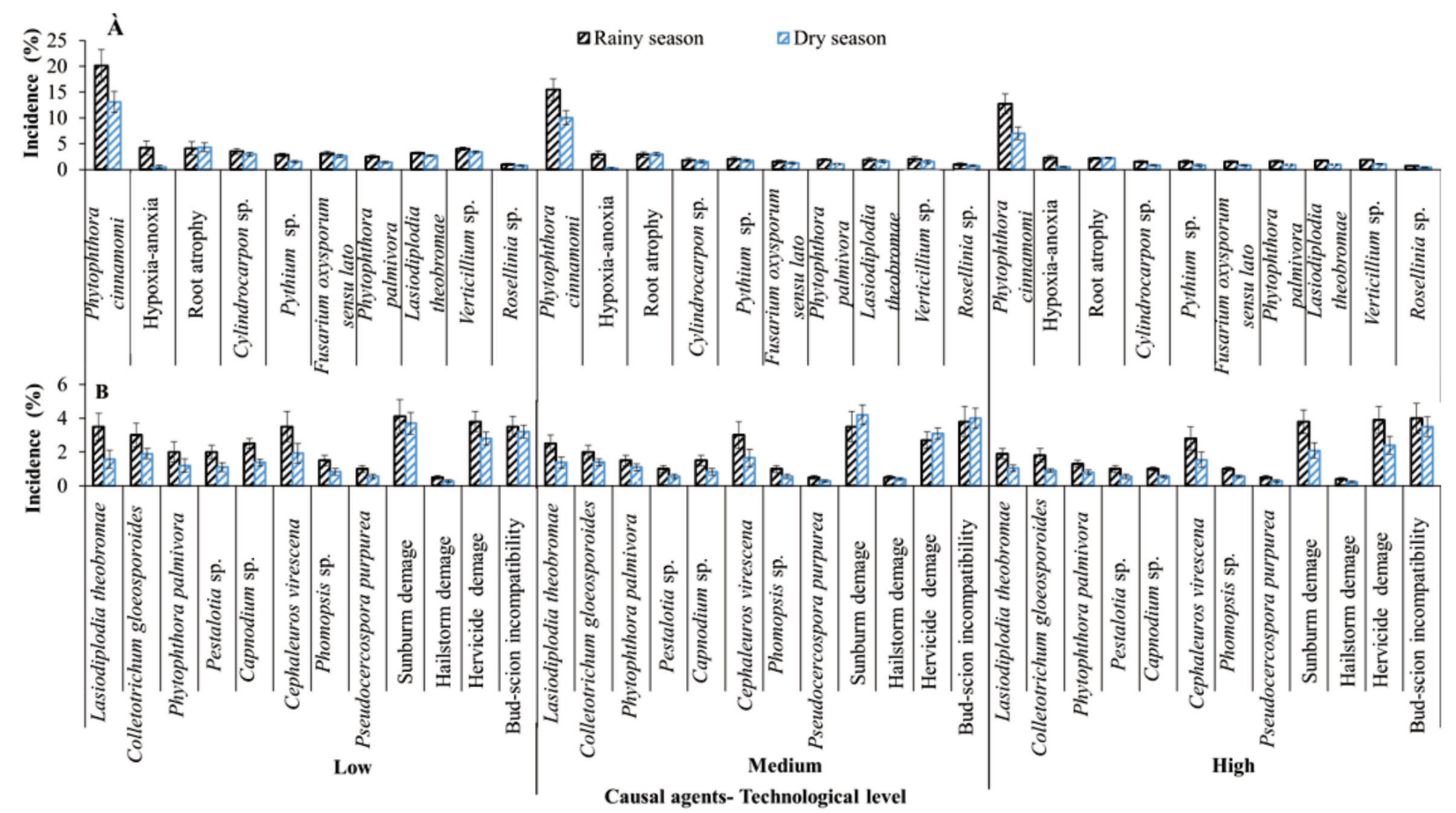

Figure 5: Disease incidence under production stages of Hass avocado with different technological levels and under contrasting environmental conditions. A: microorganism and disorder associated with avocado wilt complex. B: microorganism and disorder associated with seeds, stems, leaves, flowers and frtuis. Error bars represent the mean and confidence intervals, validated by the Dunnett, Tukey and Kramer test. Overlap of the error bars indicates that there are no significant differences $(\mathrm{P}>0.05)$. 
microbial structures in the soil before transplantation or in other plant hosts may determine high incidence and mortality rates. Examples of such a situation have been reported for Rosellinia sp. in fields where coffee was previously grown (Castro, 1999); Verticillium sp., in solanaceous hosts (Ramírez-Gil et al., 2017a); and Fusarium oxysporum sensu lato (Dean et al., 2012).

Some pathogens were found associated to diseases in all crop stages tested, in tissues different to roots. Severe damage and mortality in the grafting zone was caused by Colletotrichum gloeosporioides sensu lato and $L$. theobromae, during nursery and transfer to the field stages. The same fungi caused fruit rot making them important as post-harvest pathogens (Maftoonazad et al., 2007; Bosse et al., 2013). P. palmivora was notorious for affecting three different tissues, i.e., roots, stems and foliage. Abiotic factors such as sun light, herbicides and bud-scion incompatibility have been less studied, despite of causing large losses. Therefore more attention should be paid to these neglected causal agents when planning research on or planting avocado plots (Frolich et al., 1958). The high mortalities registered by Rosellinia sp., Verticillium sp., Fusarium oxysporum sensu lato, L. theobromae and Colletotrichum gloeosporioides sensu lato, indicate their importance in spite of being less studied than $P$. cinnamomi.

Our results suggest that diseases and disorders found in plots of avocado evaluated were modulated by three factors, (i) technological level of the farm, (ii) sampling season and (iii) environmental and topographical variables of cultivated plots (Figures 4 and 5).

The technological level of the farm was identified as a crucial determinant of disease incidence and mortality, including all the agronomical practices carried out such as plot selection, seedling quality and others (Ramírez-Gil et al., 2017b; Ramírez-Gil, 2018). In previous work, highlighted the importance of incorporating agronomical practices with high technological level as a fundamental part of an integrated crop management to decrease the impact pathologies may cause in avocado production (Ramírez-Gil \& Peterson, 2019).

The positive relationship obtained between avocado disease and precipitation, and soil moisture, confirm a number of previous reports suggesting that climatic information may be useful for intensification of prevention, monitoring and control practices, to reduce disease incidence in critical periods such as those of high precipitation (Zentmyer, 1980; Kinal et al., 1993; RamírezGil, 2018). In additions, the slope of the plots partially determines water flow within the soil profile and in consequence may influence disease onset. In the low slope places, AWC caused by P. cinnamomi and hypoxiaanoxia was higher than in the higher slope zones, suggesting that the topography of the plot is a factor that should be carefully considered when planning an avocado crop (Zentmyer, 1980; Kinal et al., 1993; Ramírez-Gil, 2018; Ramírez-Gil \& Peterson, 2019).
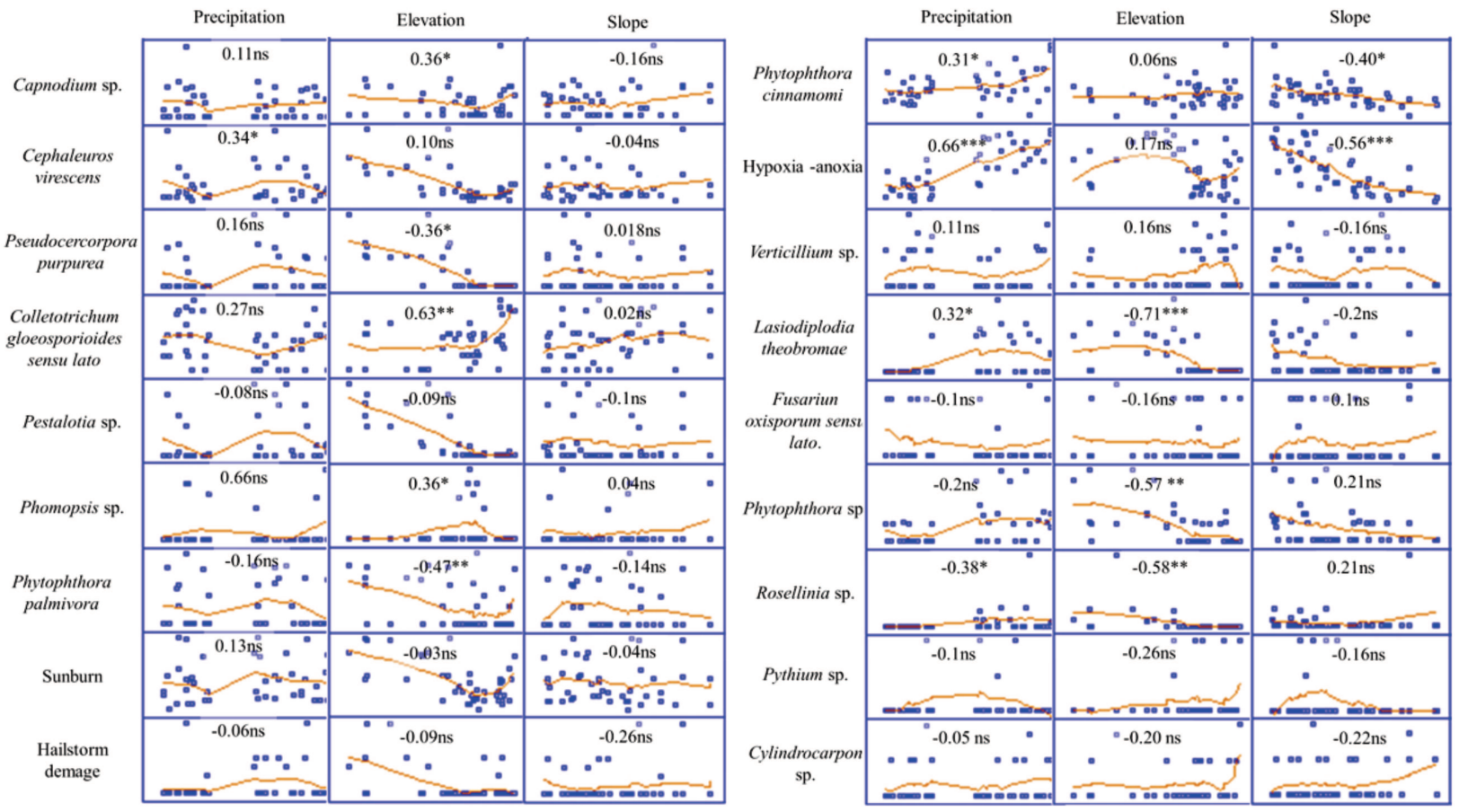

Figure 6: Correlation between incidence of causal agents associated with diseases and disorders in avocado cv. Hass and environmental and topographic variables. Statistics based on Spearman correlation Rank. ns $=$ not significant. $*=\mathrm{P}<0.05$, ** $=\mathrm{P}<0.01, * * *=\mathrm{P}<0.001$.

Rev. Ceres, Viçosa, v. 68, n.1, p. 071-082, jan/feb, 2021 
In the tropics, the elevation is one of the factors that influences climatic variables such as temperature, dew point, humidity and others that are important for disease development (Malhi et al., 2010). In the present work, Capnodium sp., Colletotrichum gloeosporioides sensu lato and Phomopsis sp. were favored at elevations between 2200-2500 masl, meanwhile $P$. purpurea, $L$. theobromae, P. palmivora and Rosellinia sp. were more prevalent below 2200 masl.

As diverse biological and environmental factors influence disease development in a complex network of interactions, knowledge in all aspects of research and fruit production should be integrated for a better prevention, diagnosis and management of avocado production. As edaphoclimatic conditions are highly variable in the tropical highlands where avocado cv. Hass is grown, further research including more regions with contrasting parameters may widen our current knowledge of the complex interactions that occur during disease emergence and development (Ramírez-Gil, 2018).

\section{CONCLUSION}

AWC disease is the most important pathology and disorder in avocado, and this is associated with different casual agents, when $P$. cinnamomi presented the highest relevance. In addition, pathologies associated with root presented more incidence than pathologies associated with other tissues (stem, leaves, and fruits). Incidence of diseases in avocado plantations located in Antioquia, Colombia, depends mainly in the technological level of the crop system, the sampling season (rainy / dry) and topographic variables of the orchard such as slope and altitude.

\section{ACKNOWLEDGEMENTS, FINANCIAL SUPPORT AND FULL DISCLOSURE}

Universidad Nacional de Colombia provided partial funding, and Colciencias provided the $\mathrm{Ph}$. D. scholarship of the first author. This research did not receive any specific grant from funding agencies in the public, commercial, or not-for-profit sectors. The authors declare that they have no conflict of interest. This article does not contain any studies with human participants or animals performed by any of the authors.

\section{REFERENCES}

APS (2017) Diseases of Avocado (Persea americana Miller) Available at: www.apsnet.org/publications/commonnames/Pages/ Avocado.aspx. Accessed on: August 9 2019.

Bate AM, Jones G, Kleczkowski A, MacLeod R, Naylor J, Timmis J, Touza J \& White PC (2016) Modelling the impact and control of an infectious disease in a plant nursery with infected plant material inputs. Ecological Modelling, 334:27-43.
Bosse RJ, Bower JP \& Bertling I (2013) Systemic resistance inducers applied preharvest for Colletotrichum gloeosporioides control in avocados. Acta Horticulturae, 1007:153-160.

Castro B (1999) Las Llagas del cafeto. Avances Técnicos Cenicafé, 268:1-8.

Cochran W (1977) Sampling Techniques. $3^{\text {rd }}$ ed. New York, John Wiley \& Sons. 448p.

Dean R, Van Kan JAL, Pretorius ZA, Hammond-Kosack KE, Di Pietro A, Spanu PD, Rudd JJ, Dickman M, Kahmann R, Ellis J \& Foster GD (2012) The Top 10 fungal pathogens in molecular plant pathology. Molecular Plant Pathology, 13:414-430.

FAO (2020) FAOSTAT. Available at: http://www.fao.org/faostat/ es/\#home. Accessed on: January $9^{\text {th }}, 2020$.

Frolich E, Schroeder C \& Zentmyer G (1958) Graft compatibility in the genus Persea. California Avocado Society Yearbook, 42:102-105.

Giblin FR, Tan YP, Mitchell R, Coates LM, Irwin JAG \& Shivas RG (2018) Colletotrichum species associated with pre-and postharvest diseases of avocado and mango in eastern Australia. Australasian Plant Pathology, 47:269-276.

Gudmundsson J, Hammar M \& van Kreveld M (2002) Higher order delaunay triangulations. Computer Geometry Theory Applied, 23:85-98.

Hardham AR \& Blackman LM (2018) Phytophthora cinnamomi. Molecular Plant Pathology, 19:260-285.

Kinal J, Shearer BL \& Fairman RG (1993) Dispersal of Phytophthora cinnamomi through lateritic soil by laterally flowing subsurface water. Plant Disease, 77:1085-1090.

Lau MK (2013) DTK: Dunnett-Tukey-Kramer pairwise multiple comparison test adjusted for unequal variances and unequal sample Sszes. Available at: https://CRAN.R-project.org/package=DTK. Accessed on: January $20^{\text {th }}, 2020$.

MacDonald JD, Ali-Shtayeh MS, Stites J \& Kabashima J (1994) Occurrence of Phytophthora species in recirculated nursery irrigation effluents. Plant Disease, 78:607-611.

Madden LV, Hughes G \& Bosch F van den (2007) The study of plant disease epidemics. Saint Paul, American Phytopathological Society. 432p.

Maftoonazad N, Ramaswamy HS, Moalemiyan M \& Kushalappa AC (2007) Effect of pectin-based edible emulsion coating on changes in quality of avocado exposed to Lasiodiplodia theobromae infection. Carbohydrate Polymers, 68:341-349.

Malhi Y, Silman M, Salinas N, Bush M, Meir P \& Saatchi S (2010) Introduction: elevation gradients in the tropics: laboratories for ecosystem ecology and global change research. Global Change Biology, 16:3171-3175.

Menge JA \& Ploetz RC (2003) Diseases of avocado. In: Ploetz RC (Ed.) Diseases of tropical fruit crops. Wallingford, CABI p.35-71

Parkinson LE, Shivas RG \& Dann EK (2017) Pathogenicity of Nectriaceous fungi on avocado in Australia. Phytopathology, 107:1479-1485.

R Development Core Team (2020) R: A Language and environment for statistical computing. Vienna, R Foundation for Statistical Computing. Available at: https://www.r-project.org. Accessed on: June $9^{\text {th }}, 2020$.

Ramírez-Gil J (2018) Avocado wilt complex disease, implications and management in Colombia. Revista Facultad Nacional de Agronomía Medellín, 71:8525-8541.

Ramírez-Gil J \& Morales-Osorio JG (2019) Polyphasic identification of preharvest pathologies and disorders in avocado cv. Hass. Agronomía Colombiana, 37:213-227. 
Ramírez-Gil JG, Gil-Aguirre A \& Morales-Osorio JG (2017a) Etiology of tree tomato (Solanum betaceum CAV.) diseases Revista de Protección Vegetal, 32:33-51.

Ramírez-Gil JG, Gilchrist Ramelli E \& Morales Osorio JG (2017b) Economic impact of the avocado (cv. Hass) wilt disease complex in Antioquia, Colombia, crops under different technological management levels. Crop Protection, 101:103-115.

Ramírez-Gil JG \& Peterson AT (2019) Current and potential distributions of most important diseases affecting Hass avocado in Antioquia Colombia. Journal of Plant Protection Research, 59:214-228.

Sanclemente MA, Schaffer B, Gil PM, Vargas I \& Davies FS (2014) Pruning after flooding hastens recovery of floodstressed avocado (Persea americana Mill.) trees. Scientia Horticulturae, 169:27-35.

Stolzy L, Zentmyer G, Klotz L \& Labanauskas C (1967) Oxygen diffusion, water, and Phytophthora cinnamomi in root decay and nutrition of avocados. American Society for Horticultural science, 90:67-76
Valencia AL, Gil PM, Latorre BA \& Rosales IM (2018) Characterization and pathogenicity of Botryosphaeriaceae species obtained from avocado trees with branch canker and dieback and from avocado fruit with stem end rot in Chile. Plant Disease, 103:996-1005.

Vitale A, Aiello D, Guarnaccia V, Perrone G Stea G, \& Polizzi G (2012) First report of root rot caused by Ilyonectria (=Neonectria) macrodidyma on avocado (Persea americana) in Italy. Journal of Phytopathology, 160:156-159.

Weiland JE, Beck BR \& Davis A (2013) Pathogenicity and virulence of Pythium species obtained from forest nursery soils on Douglas-Fir seedlings. Plant Disease, 97:744-748.

Zentmyer G (1980) Phytophthora cinnamomi and diseases it causes. Riverside, Phytopathol Society. 80p.

Zentmyer G (1984) Avocado diseases. Tropical Pest Management, 30:677-682. 